\title{
2017 International Meeting Society of Biblical Literature and European Association of Biblical Studies, Humboldt-Universität zu Berlin, Germany, 7.-11. 8. 2017
}

J A R O L A B R O Ž

V prázdninových dnech roku 2017 hostila slavná berlínská univerzita, nesoucí jméno významného přírodovědce Alexandra von Humboldta, velký počet badatelů z oblasti biblistiky a př́buzných oborů. Na společnou konferenci Society of Biblical Literature a European Association of Biblical Studies se do německé metropole sjelo 1169 účastníků, kteří pracovali ve 324 sekcích a 54 programových jednotkách.

Vedle tradičních témat, která lze vymezit základními skupinami starozákonních a novozákonních knih, tj. Pentateuch, historické knihy, proroci, mudroslovná literatura, apokalyptika, synoptická evangelia, epištoly a Janovo Zjevení, měly na konferenci prostor i tradiční a nové metodologické a hermeneutické přístupy, k nimž patří bádání o historickém Ježí̌ii, Bible a ekologie, význam metafory v Bibli, konstruktivismus a dekonstruktivismus a další. Některé sekce se věnovaly výzkumu na poli judaistiky, islámu, dějin Blízkého východu a kulturních studií.

Za zvláštní zmínku stojí témata, která byla připravena berlínskými organizátory konference. $\mathrm{Z}$ celkem dvaceti čtyř nabídek připomeňme například „500 let po Erasmovi: Kde se dnes nachází novozákonní textová kritika?“, „Židovské biblické bádání v Berlíně“, „Bible a její recepce ve východoevropském bádáni“" nebo „Revidovaná Lutherova Bible 2017 a další současné př́ístupy v německých biblických překladech v 21. století“. Osobní a lidský ráz vědeckých sympozií podtrhují mimo jiné neformální večerní setkání se známými osobnostmi vědy. Berlínská konference se mohla pochlubit přítomností takových jmen, jako jsou kumránští badatelé Devorah Dimant, Émile Puech a Peter Machinist, starozákoník Rudolf Smend nebo významný nèmecký judaista Peter Schäfer, který jako současný ředitel berlínského židovského muzea pozval účastníky k jeho návštěvě.

Vzhledem k zeměpisné i kulturní blízkosti Berlína byli na konferenci hojně zastoupeni i čeští akademici. V sekci List Židům vystoupil Jaroslav Brož s příspěvkem „Potřeboval se Ježíš stát dokonalým? Jak chápat pojem dokonalosti v Listu Židům" (Did Jesus Need to be Made Perfect? A Possible Concept of Perfection in the Epistle to the Hebrews), a Eliška Havelková s příspěvkem „Ježíš - posvěcovatel v Listě Židům“ (Jesus, the Sanctifier in the Epistle to the Hebrews). Ta přednesla v sekci Etika v Didaché a Hermově Pastýři svůj druhý příspěvek na téma „Svatí v Didaché“ (The Saints of Didache). Petr Pokorný přispěl do sekce Lukáš -Skutky: Tradice, imitace, alusivita a inovace svým 
referátem na téma „EPI TO AYTO v životě rané církve podle Skutků apoštolů“ (The EPI TO AYTO in the Life of the Early Church According to the Book of Acts). Ve starozákonní skupině Pojetí vůdcovství u proroků Aggea a Zachariáše byl zapojen Jan Rückl jako respondent ke dvěma referátům. V sekci Procesy přepisování: Subverse a záchrana trvání kanonického materiálu přednesla Barbara Oudová Holcátová svůj příspěvek na téma Negotiating (with) Canon in Tolkien Fan Fiction. A konečně Libor Duchek přispěl do sekce Ústní kultura a gramotnost u Pavla v pavlovské teologii svým tématem „Jaký obraz mèli Římané o apoštolu Pavlovi? Řeči a klepy v Listě Římanům" (What picture did have Romans about the Apostle Paul? Rumours and gossip in the Letter to Romans).

Jestliže každá konference díky bohaté odborné náplni, počtu osobních setkání se starými přáteli i s novými tvářemi potenciálních budoucích spolupracovníků, kulturnímu rámci dané lokality a jejímu geniu loci je velikým svátkem vědy, pak - podle mého subjektivního dojmu i podle sdílených zkušeností dalších účastníků - berlínská konference jím byla bezesporu dvojnásob. Za to patří dík všem př́ítomným, ale zejména pořádající instituci a organizačnímu týmu.

Účast autora tohoto príspèvku na konferenci byla soućástí plnèni projektu GA ČR P401/12/G168 „Historie a interpretace Bible“ financovaného Grantovou agenturou České republiky.

doi: 10.14712/23363398.2018.25 